The Iron and Steel Institute

\title{
FOULING OF
}

\section{SHIPS' BOT'TOMS :}

\section{IDENTIFICATION \\ OF}

\section{MARINE GROWTHS}

BY THE

MARINE CORROSION SUB-COMMIT'TEE
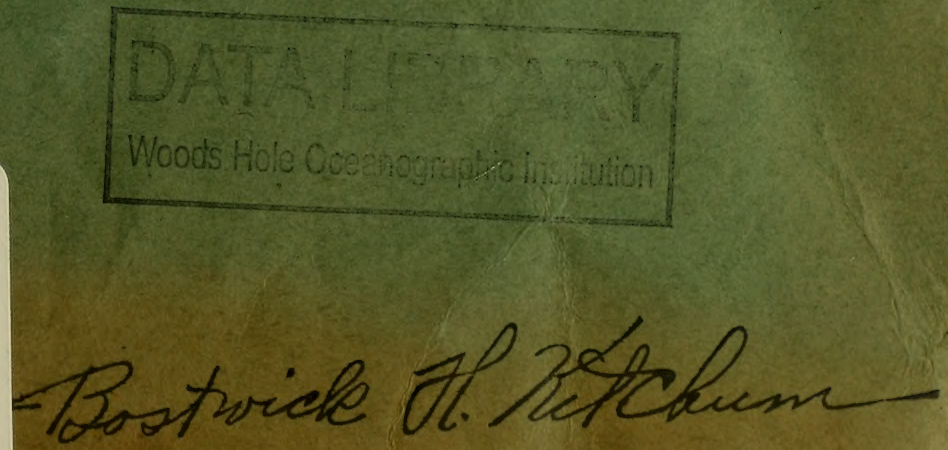


\title{
FOULING OF SHIPS' BOTTOMS :
}

\section{IDENTIFICATION OF MARINE GROWTHS}

\author{
BY THE \\ MARINE CORROSION SUB-COMMITTEE \\ OF THE \\ GORROSION GOMMITTEE
}

A Joint Committee of

The IRON AND Steel Institute

AND

The British Iron and Steel Federation

WITH EIGHT PLATES

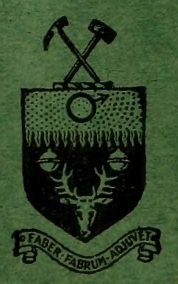

Published at the Offices of THE IRON AND STEEL INSTITUTE 4, Grosvenor Gardens, London, S.W.1. 


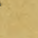




\section{This booklet which is published by the}

Iron and Steel Institute, has been prepared in collaboration with the Admiralty Corrosion Committee. Whilst its contents may appear to be of a somewhat academic nature, it is considered that it will be of use to all those who are concerned in the fouling problem of ships, or interested in natural history.

The suggested docking form in this pamphlet is for the Mercantile Marine, and must not be confused with the official docking form D.495, which is required for Naval Vessels.

Attention of all Naval and Dockyard Authorities is called to the Activities of the Admiralty Corrosion Committee vide A.F.0.2923/43. Any examples of fouling or queries arising therefrom should be referred to the Secretary of the Admiralty Corrosion Committee, Portsmouth Dockyard, and not to the officials of the Marine Corrosion Sub-Committee. 


\title{
FOULING OF SHIPS' BOTTOMS : IDENTI- FIGATION OF MARINE GROWTHS. ${ }^{1}$
}

\author{
By THE MARINE CORROSION SUB-COMMITTEE. ${ }^{2}$
}

(Figs. 2 to $45=$ Plates I. to VIII.)

Paper No. 14/1944 of the Corrosion Committee (submitted by the Marine Corrosion Sub-Committee).

\section{Contents}

(1) Objects of this Booklet

(2) The Significance of Fouling

(3) The Growth of Fouling

(4) The Anti-Fouling Problem

(5) The Fouling Organisms

(a) Slimes

(b) Plants ("Weeds")

(c) Animals

(6) The Identification of Fouling Organisms

(7) Dry-Docking Report and Key

(8) Notes on the Recognition of Specific Organisms

(a) Diatom Slimes

(b) Plants

(c) Animals

(1) OBjects OF THIS BookLet.

The objects of this booklet are :

(1) To emphasise the deleterious effects of fouling on the operation of a ship,

(2) to give a brief account of the settlement and growth of the marine organisms which are mainly responsible for fouling,

(3) to discuss briefly the methods of anti-fouling research, and the means of preventing fouling, and

(4) to describe the characteristics of marine growths in sufficient detail so that they may be correctly identified when present on ships.

A questionnaire in the form of a dry-docking report is provided on pp. 11-12. This form, additional copies of which may be obtained from the Secretary of The-Iron and Steel Institute, is intended to serve as a research tool in furthering our knowledge of the growths on ships in relation to the various factors concerned. It is hoped that as many shipowners as possible will make use of this docking report.

1 Received November 16, 1943.

2 A Sub-Committee of the Joint Corrosion Committee of The Iron and Steel Institute and the British Iron and Steel Federation reporting to the Iron and Steel Industrial Research Council. 


\section{(2) The Significance of Fouling.}

The fouling of ships by marine growths is a matter of very great importance in both the performance and the upkeep of the Royal Navy and merchant fleets.

For design purposes it is the practice of the Admiralty to allow an increase of frictional resistance of $\frac{1}{4} \%$ per day out of dock in temperate waters and $\frac{1}{2} \%$ per day in tropical waters. These figures are based on the results of experience over a number of years, and may be regarded as covering the worst conditions of fouling that are generally experienced in warships in peace-time, when a relatively large proportion of time is spent in harbours. The possible effect of fouling in producing increased fuel consumption and loss of speed is shown in Table 1., which is calculated on the basis of this Admiralty allowance for various types of ships in temperate waters. The corresponding figures under tropical conditions would be approximately doubled.

TABLE I.-Effect of Fouling for Six Months out of Dock in Temperate Waters.

Frictional resistance assumed to increase $4^{1}$ " $"$ per day.

\begin{tabular}{|l|c|c|c|c|}
\hline Trpe of ship. & $\begin{array}{c}\text { Standara } \\
\text { Displacement. } \\
\text { Tons. }\end{array}$ & $\begin{array}{c}\text { Loss of } \\
\text { Maximum } \\
\text { Speed. } \\
\text { Knots. }\end{array}$ & $\begin{array}{c}\text { Percentage Inerease in Fuel } \\
\text { Consumption * to Maintain } \\
\text { a Speed of- }\end{array}$ \\
\hline Battleship & 10 Knots. & 20 Knots. \\
Aircraft carrier & 35,000 & $1 \frac{1}{2}$ & 45 & 40 \\
Cruiser & 23,000 & $1 \frac{1}{4}$ & 45 & 40 \\
Destroyer & 10,000 & $1 \frac{1}{4}$ & 50 & 45 \\
\hline
\end{tabular}

* These figures are based on the fuel consumptions for propulsion only, i.e., auxiliaries are not ineluded.

- The foregoing examples refer to warships under peace conditions. The corresponding figures for merchant ships will in general be less, because they spend a greater proportion of time at sea and are therefore less exposed to fouling conditions. During the war, however, many serious cases of fouling of merchant ships have been reported, particularly on vessels operating in the tropies. As a result, the IIinistry of War Transport and shipowners have been considering the possibility of using more efficient compositions to meet these conditions.

Whilst it is difficult to give a reliable estimate, it is probable that at least $20 \%$ of the total quantity of fuel used for ship propulsion is expended in overcoming the increased resistance due to fouling. When to this is added the cost of the more frequent dry-dockings necessary for cleaning and coating bottoms, some idea can be obtained of the enormous ex penditure attributable to fouling. A part from the 
purely economic aspect, the problem is one of vital national importance in war-time from an operational point of view. The outcome of a naval engagement might well depend on the increased endurance and higher maximum speed that would result from a reduction of fouling.

\section{(3) The Growth of Fouling.}

When a plate painted with a non-poisonous paint is immersed in the sea at certain times of the year, a community of organisms rapidly settles upon it. Included among these organisms are :

(i) Marine bacteria, some types of which secrete a coherenu slimy film over the surface.

(ii) The young stages (spores) of seaweeds, microscopic in size, but many of them rapidly developing into typical seaweed form.

(iii) Diatoms, which are minute plant cells bccurring singly, in chains or in masses. These may form a brown slimy layer over the surface or long trailing brown threads similar in appearance to certain seaweeds.

(iv) The larval forms of many sessile marine animals. These are all microscopic free-swimming organisms capable, at a certain sharply defined stage in their development, of settling on a suitable surface, to which they attach themselves by a cementing organ. Attachment precedes a metamorphosis producing the adult organism. As the animal grows, more cementing material is laid down, ever increasing the security of attachment. This sequence occurs with the common animal fouling organisms such as barnacles, calcareous tubeworms, ascidians (sea-squirts) and polyzoa. The attachment and growth of hydroids (which belong to the animal kingdom) follow a more plant-like pattern; the larva settles and grows out over the substratum as a series of branching tubes, from which at intervals arise the stalks bearing the main body and feeding organs of the animal.

A heavily fouled surface may show a basal " carpet " of bacterial and diatom slime from which project the "stalks" of hydroids as well as diverse seaweeds, and sometimes the trailing brown filaments of certain diatoms. Barnacles, tubeworms and many other animal forms attach themselves very firmly to the paint surface, for this purpose penetrating the slime, and often the surface layers of paint, if this is fairly soft.

A very heavy growth of one type of organism is frequently accompanied by the more or less complete absence of rival forms both plant and animal, so that a badly fouled surface can usually be described in terms of a very few animal or plant types. This phenomenon is known as biological exclusion. 
Plants grow predominantly at and near the water-line, and if they are abundant there they tend to discourage most types of animal life in that area. Well below the water-line, and particularly under the turn of the bilge, lack of light prevents plant growth and the population is largely, if not entirely, animal.

Several factors influence the degree of fouling which may appear on a non-toxic surface; the more significant of these include the season of the year, the amount of light reaching the submerged surface, the temperature of the water, and, perhaps the most important, the geographical location of the waters concerned. The colour of the painted surface is relatively unimportant.

Many fouling organisms have a restricted breeding period; this is illustrated in Fig. 1, which has been compiled at two observational

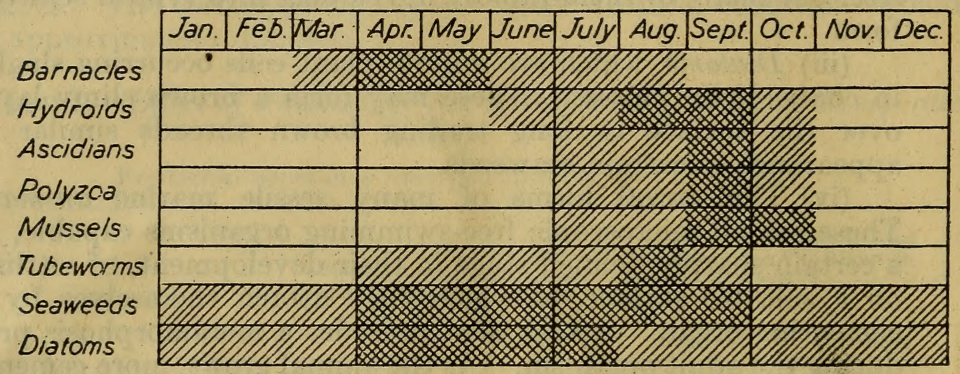

FiG. 1.-The Fouling Season at Caernarvon and Millport 1941-42. Heavy settlement is indicated by cross-hatching, the period of lighter infection by single hatching. (Ascidians $=$ sea-squirts. Diatoms correspond chiefly to those inhabiting the slime layer on ships.)

stations, Caernarvon and Millport, during the two years 1941-42. The seasonal settlement of fouling organisms naturally varies according to the locality, but the diagram may be taken as being indicative of behaviour around the coasts of Great Britain. In some tropical ports, it is known that the seasonal variation in settlement is much less marked than in home waters and that extensive fouling will occur nearly all the year round.

Fouling occurs when ships are in port or at anchor in shore waters, since the usual fouling organisms live in or near shore waters. The ports of the world vary considerably in their liability to produce fouling. As a rule, ports in the trópics are more troublesome than those in temperate climates. Most marine fouling organisms will not survive in fresh water, and hence in ports into which river waters run the variety of plant and animal life that may appear is curtailed or that acquired in a sea-water port may perish and sooner or later fall off. The shells of barnacles and tubeworms remain attached to the ships long after the animal is dead, but become very brittle. One species of barnaele (Balanus improvisus) is reputed to 
have caused severe fouling in almost fresh water (e.g., the river Plate).

\section{(4) The Anti-Foulnag Problem.}

The present-day method of combating fouling on the underwater plating of ships is the use of anti-fouling compositions appliea just prior to undocking. These compositions may contain as poisons copper and mercury compounds and organic substances. In water, these poisons leach out of the paint medium, so that a more or less continuous supply of poison is available at the surface of the paint film. The value of an anti-fouling composition depends on the rate of leaching of the toxic ingredients, which in turn is a function of the type of medium employed to bind the paint and of the percentage of toxic ingredients present. All anti-fouling compositions thus have a limited life, which for most commercial products is of the order of 4-12 months. Thus, periodical renewals of anti-fouling compositions are determined by this limited life.

The actual anti-fouling mechanism is being actively investigated at the present time. Available evidence indicates that the toxicity of a surface has little effect on the growth of an organism once attachment has taken place, so that the main line of attack lies in the prevention of the initial attachment. The constituents of the anti-fouling composition may thus include substances which exert a repellent or lethal action on the larvæ and spores, or alternatively substances which prevent the adhesion or setting of the cementing substances produced by many of the organisms for effecting the attachment. It is also possible to eliminate attachment by exfoliation, i.e., the continual shedding of the surface layer of a suitably compounded paint.

A brief summary of the Sub-Committee's investigations which are now in progress on this matter will be appropriate. Tests are being made on formulated anti-fouling compositions containing inorganic and organic poisons. It has been found that mercury is approximately twice as effective as copper against weed fouling (weight for weight) and three times as effective against barnacle fouling. Inorganically combined arsenic is almost ineffective. Although many organic poisons have been found which are very much more potent than copper and mercury when in solution in sea water, unfortunately in most cases this toxicity is difficult to bring into effect when the organic poison is incorporated in a paint film. There are, however, certain promising developments in this connection. A new technique has been developed for studying the leaching rate of poisons from paint films immersed in sea water.

An important aspect which is receiving consideration is the paint medium in which the poisons are incorporated, due regard being paid to the conflicting requirements that the poisons shall be readily and continuously available whilst the coating shall be as durable as 
possible. In all this work the importance of providing efficient protective undercoats has been stressed, since premature failure of the undercoats invariably leads to unrestricted fouling, apart from the incidence of corrosion troubles.

It will be realised that the problem of fouling is indeed a complex one requiring the collaboration of the marine biologist and other specialists. It is equally desirable that all those who are concerned with ships and shipping at sea or in dock should be familiar with the broader aspects of the problem and the methods by which it is being tackled. It is hoped, therefore, that this booklet will serve a useful purpose in stimulating the interest and co-operation of all concerned, and at the same time provide a useful guide to the identification of the marine organisms which cause fouling.

\section{(5) The Fouling Organisms.}

On a ship that has remained for a long period of time in a harbour and is then dry-docked, perhaps in that same harbour, without an intervening sea voyage, an enormous number of different types of organisms may be found growing. Not all of these forms are attached to the surface of the vessel, for in the miniature forest of growth all sorts of creeping and swimming forms find a comfortable berth. In addition, many of the attached forms have anchorages which will not stand up to the rapid motion of a ship at sea. In this booklet attention will be concentrated on those forms which are likely to be found in the normal course of a vessel's work, when she is dry-docked at the end of a trip with relatively little opportunity for the settlement of the temporary lodgers which may occur in the harbour and approaches to dry-dock' areas.

The limitation of the description to the "permanent" lodgers has two advantages: There are surprisingly few types to describe, which simplifies the problem of identifying them; also, since the temporary inhabitants will all be rapidly washed off when the ship puts to sea, they are not important in causing resistance to the motion of the ship.

Marine fouling growths appear either as slimes, as tresses of marine plants or in the highly individual forms shown by the marine animals. The animals and slime may occur over the whole submerged surface ; the tresses produced by plant growth rarely extend more than a few feet below the water-line.

\section{(a) Slimes.}

The nature of the slimes that occur on ships can be recognised only by microscopic examination. Commonly they appear structureless under a magnification less than $\times 100$, and such slimes are probably formed by bacteria. Others, which are usually rather tougher, are formed by one-celled plants called diatoms. They live 
in countless numbers, often closely packed together, within the slime which they themselves produce (see Fig. 40). The contents of the cells are brown or olive-yellow in colour.

\section{(b) Plants ("Weeds").}

The seaweeds that form the "grass" on the upper parts of the underwater plating are of diverse kinds like the seaweeds found in rock pools on our own shores. They may be green, light or dark brown, bright red or purple in colour (Figs. 2 to 8 ), and may rearh a length of several inches.

\section{(c) Animals.}

The best-known of all the animal fouling organisms (Figs. 9 to 16) are the barnacles. The form of these, with their conical shells adhering firmly to the hull surface, is almost too well-known to need description.

The common type of barnacle, the "acorn barnacle" (Figs. 12 and 21), is most usually encountered, but occasionally stalked or "goose barnacles" occur. The latter are attached to the hull br a thick muscular stalk up to 3-4 in. in length, at the end of which is the body with its shell (Fig. 22), which may be inconspicuous.

The shellfish (molluscs) which foul ships are represented by the mussels and oysters (Figs. 13 and 14). They are not likely to be mistaken for any other forms, since the shell is always formed from two halves called "valves." They frequently occur in large numbers on the various underwater gratings of the ship; when they grow on the hull itself they show that the anti-fouling coating has completely broken down, since they are very easily poisoned.

Tubeworms, as their name suggests, appear as white or greyish limy tubes, which may be much coiled, lying flat against the surface or sometimes projecting outwards from it (Figs. 11 and 17). They often occur in patches on the hull surface (when they are frequently but incorrectly called " coral patches"). They are of considerable importance in the fouling of propeller blades (Fig. 18). Their very long and firm attachment anchors them well even on a rapidly rotating screw, where they may occur along almost the whole length of the blade, causing a very serious reduction in the propulsive efficiency. They are fairly sensitive to poisonous paints, and hence their settlement on the hull indicates poor anti-fouling properties.

All the above forms possess shells which remain on the hull even when the animal is killed, e.g., by steaming through a fresh-water zone. Other animal forms without limy shells can oceur either as plant-like branching growths (e.g., hydroids) or jelly-like soft-bodied forms.

Hydroids (Figs. 9 and 10) are often important fouling organisnis, since they are firmly attached and some are very resistant to anti- 
fouling paints. The most usual forms occur in patches or clumps of knobbed stalks, which are much stiffer than those of fouling seaweeds, so that they stand out from the hull surface even when in dry-dock. The tresses of seaweeds almost always collapse against the surface when the water is withdrawn. One of the commonest forms of hydroid in British waters (Tubularia, Fig. 10) has a very striking bright pink head to the stalk. These heads disappear under unfavourable conditions (e.g., fresh water, low temperature, $\& c$.$) , but the stalks persist and form characteristic stiff, wiry grey$ clumps.

The soft-bodied forms include the sponges (Figs. 19 and 26), sea-squirts (Figs. 20 and 25) and sea-anemones (Fig. 27).

\section{(6) The Identification of Foulinc: Organisms.}

It is impossible to give an absolutely hard and fast rule for the identification of any particular type of fouling organism. The key in Section (7) gives a reasonably accurate method of establishing the principal groups without going into detail, which can be seen only under a hand-lens or microscope. Whenever doubtful cases occur, a small sample can readily be preserved in water to which a few drops of formalin have been added. The Marine Corrosion SubCommittee will gladly examine and identify any specimens sent to them, and will supply tubes of formalin to anyune wishing to send samples; correspondence on this subject should be addressed to the Secretary of The Iron and Steel Institute.

In using the dry-docking report, the following general remarks should be borne in mind. Seaweeds are almost always confined to the water-line area; if a plant-like growth occurs over the whole or the darker parts of the hull it is probabiy a hydroid. A green colour is an almost certain mark of a seaweed, but the latter may also be red or brown. A red seaweed is usually of a fairly rich deep colour, the stalk as well as the "branches" being all of one colour. The red colour of some hydroids is limited to the knobbed head alone; the stalks (which may not bear any head at all) are usually greyish, brown or white. A diatom slime may look like a patch of brown oil ; it is not, however, greasy, and washes off the fingers easily with water; when dry it often appears as a grey or greenish-grey film.

The recognition of the various kinds of plant growths, both diatoms and seaweed, that occur on fouled vessels is most satisfactorily accomplished by the use of the microscope, a magnification of 100 diameters being adequate for this purpose. Some seaweeds are, however, difficult to distinguish from one another except by an expert. Some identification is possible by examining plant growths with a good hand-lens; for this purpose it is advisable to spread them out thinly on the fingers or in water between two small sheets of glass, examining them against a strong light. 
Seaweeds and Hydroids.

Rather less than Natural Size.
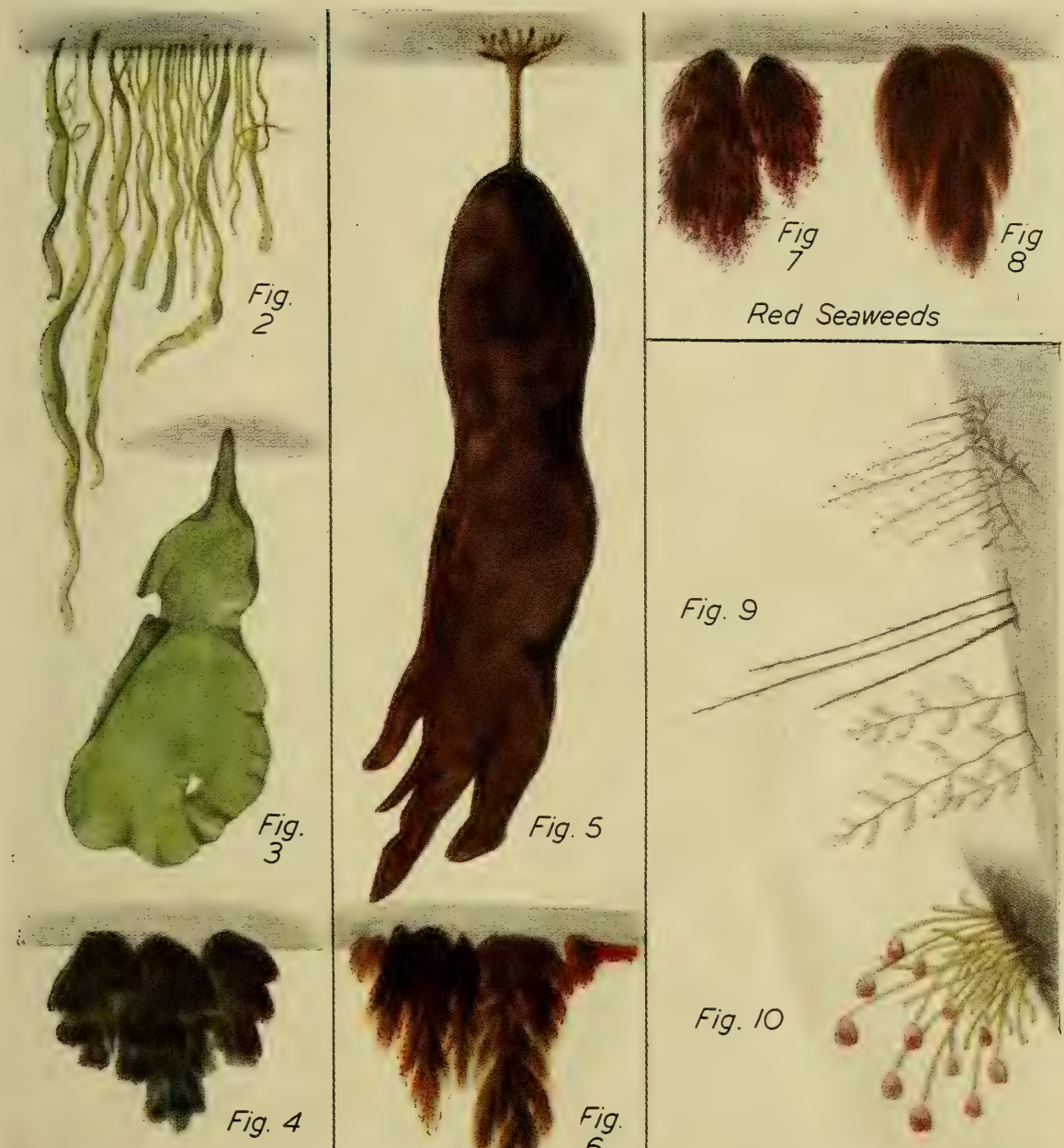

Green Seaweeds

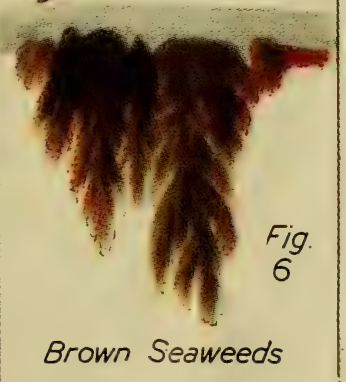

Fig. 2.-Enteromorpha.

Fig. 3.-Ulva.

hyig. 6.-
Fig. 7.-Ceramium.

Fig. 4.-Cladophora. Fig. 8.-Polysiphonia. Fig. 10. - Tubularia (a common hydroid).

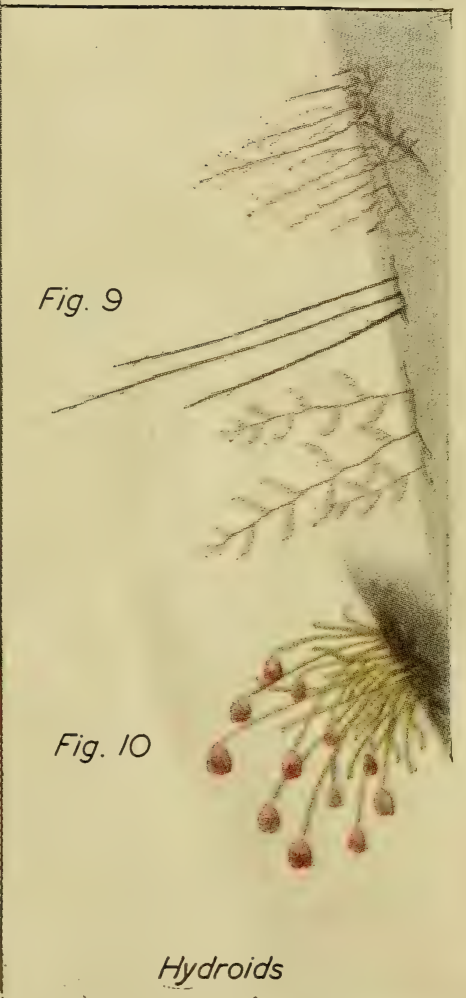

Hydroids 
Various Animal Fouling Organisms.

Rather less than Natural Size.

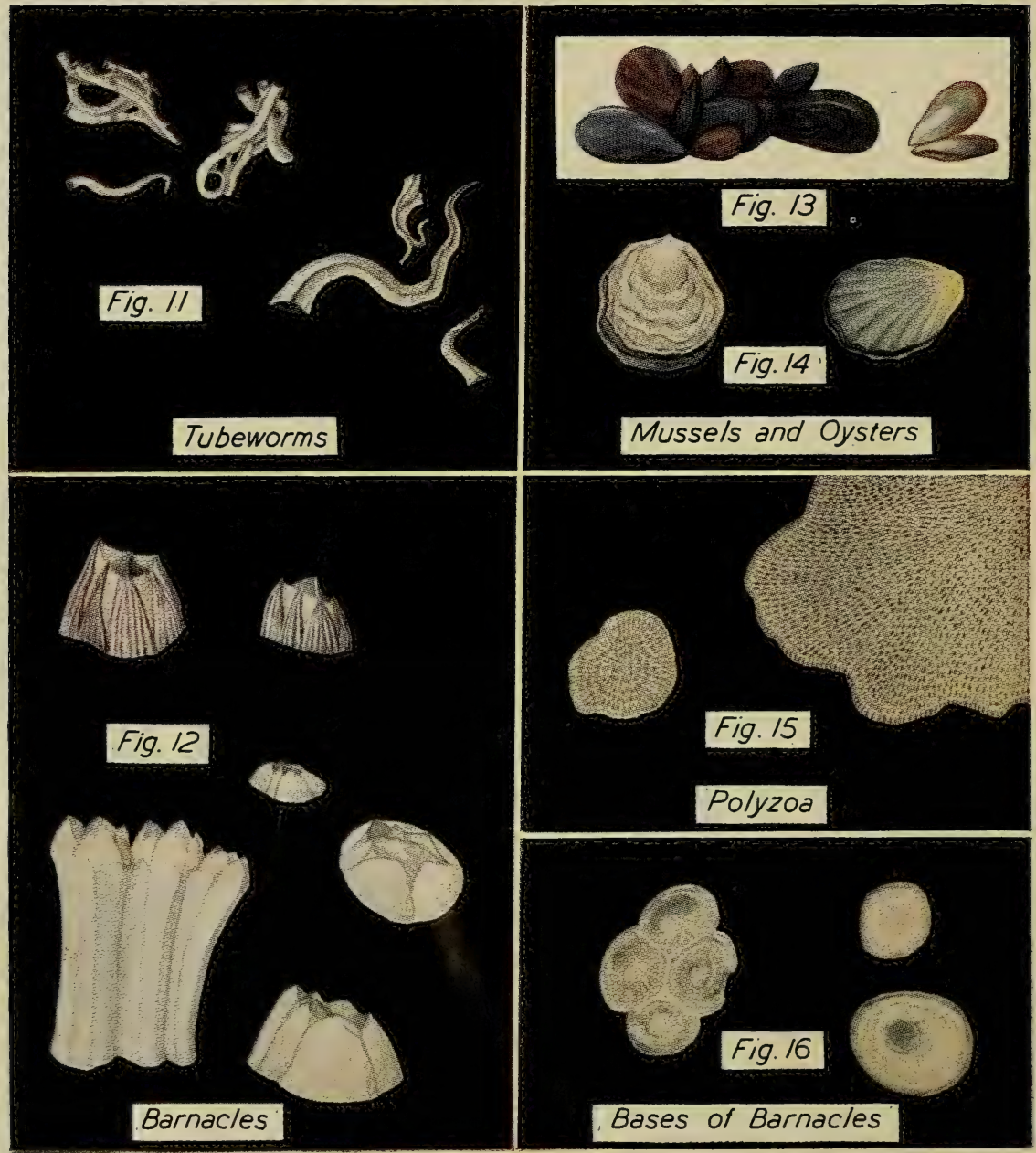

Fig. 11.-Tubeworms.

Fig. 12.-Barnacles. The coloured type is a tropical and sub-tropical form; the white ones are a typical British species. The elongated form assumed when the barnacles are tightly packed is also shown.

of encrusting Polyzoa.

Fig. 13.-Mussels.

Fig. 14.-Oysters.

Fig. 15.-Patches

or been removed by scraping.

Fig. 16.-Bases of barnacles after the barnacles themselves have fallen off

[Fouling of Ships. 
Actual Fouling Observed in Dry-Dock.

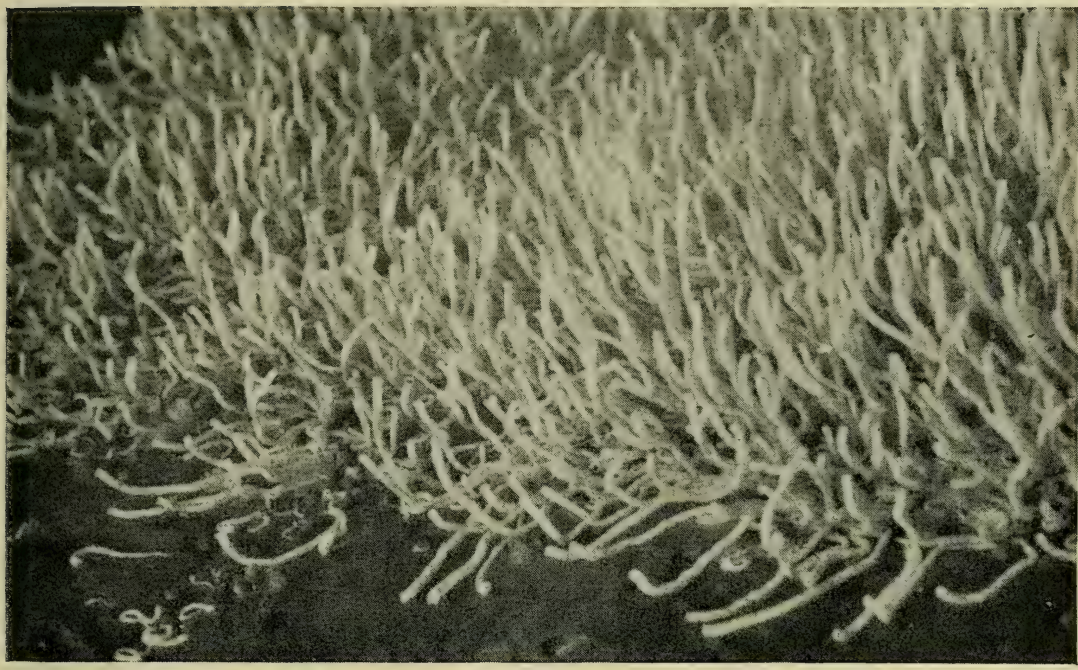

Fig. 17. - A heavy tubeworm infection as seen on the actual vessel in dry-dock.

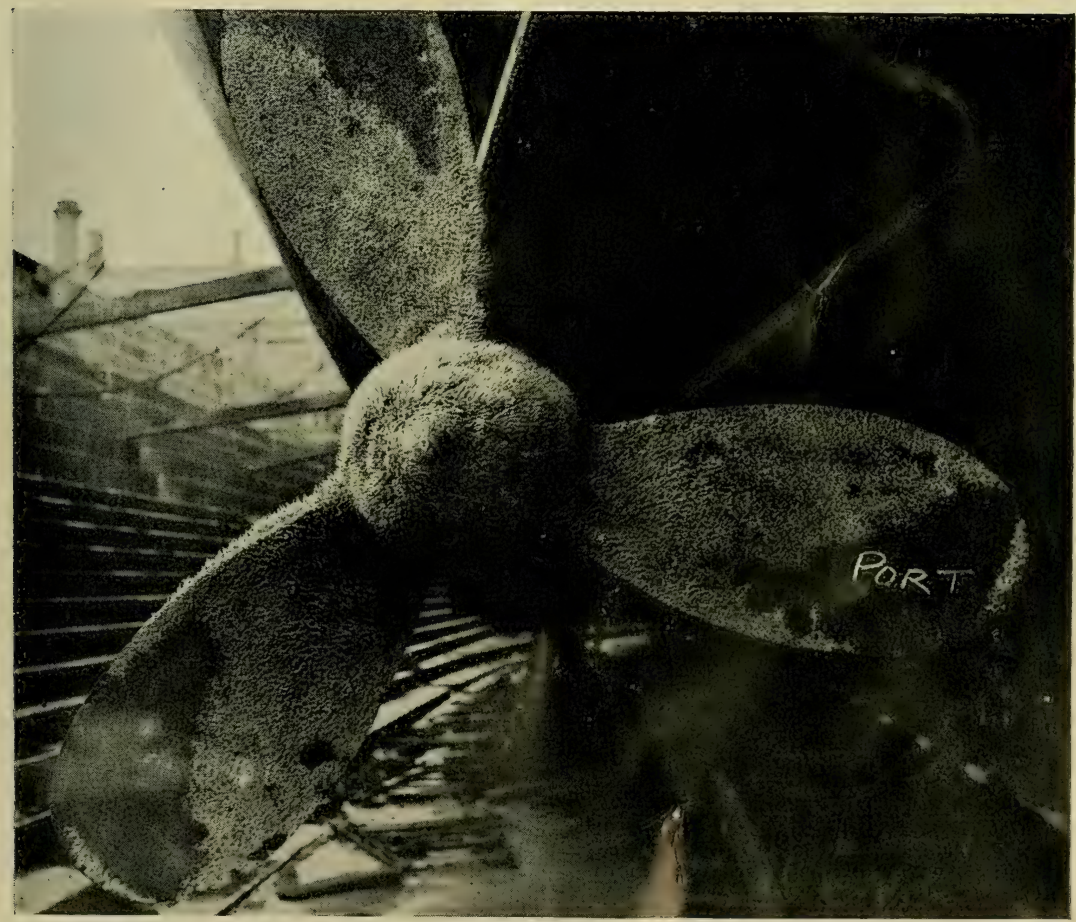

Fig. 18. - Fouling of propeller of H.M.S. Fowey by calcareous tubeworms. (Reproduced, by courtesy, from G. D. Bengough and V. G. Shepheard, "The Corrosion and Fouling of Ships," Transactions of the Institution of Naval Architects, 1943, vol. 85, p. 1.) 

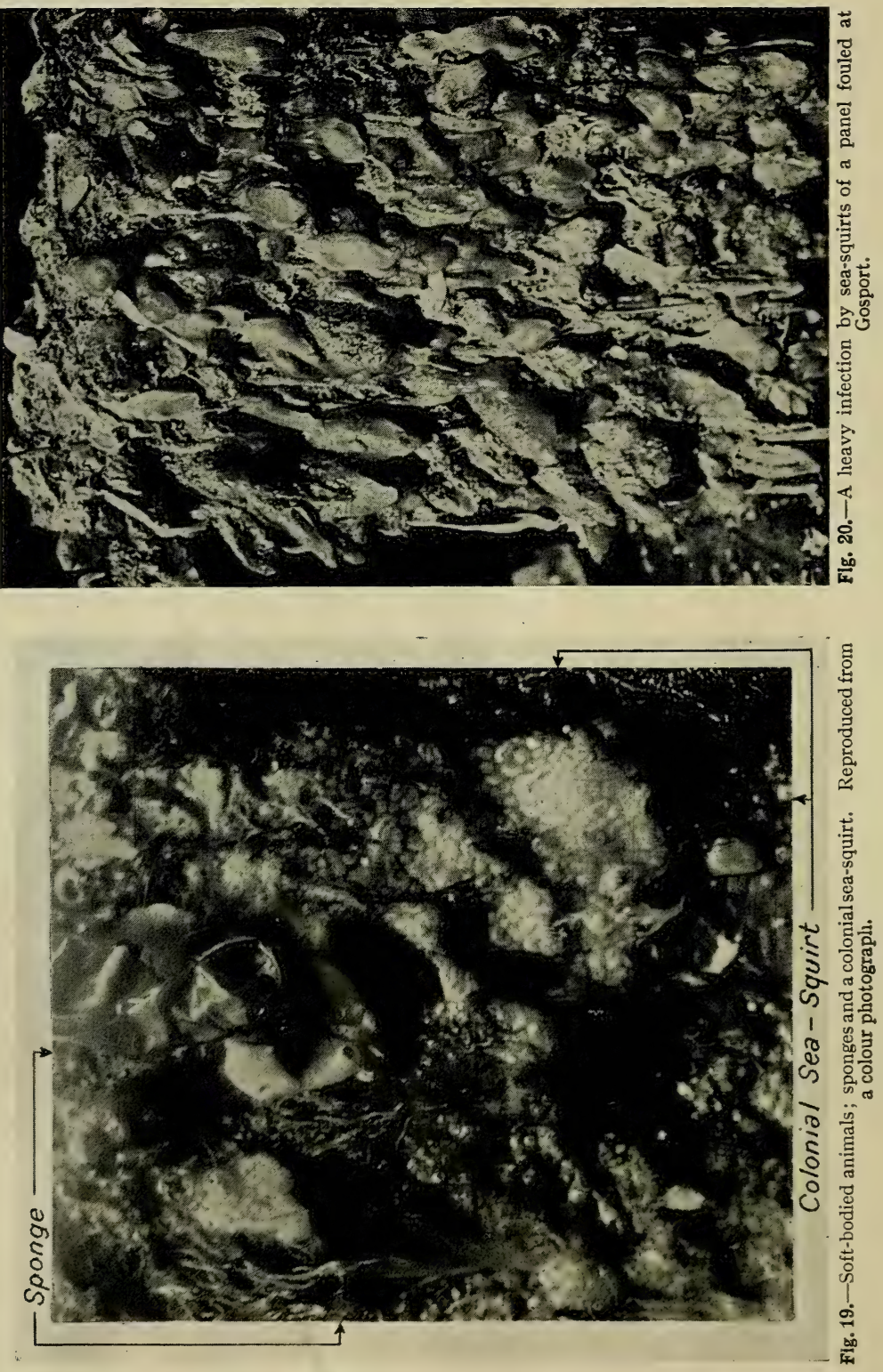
Various Animal Fouling Organisms.
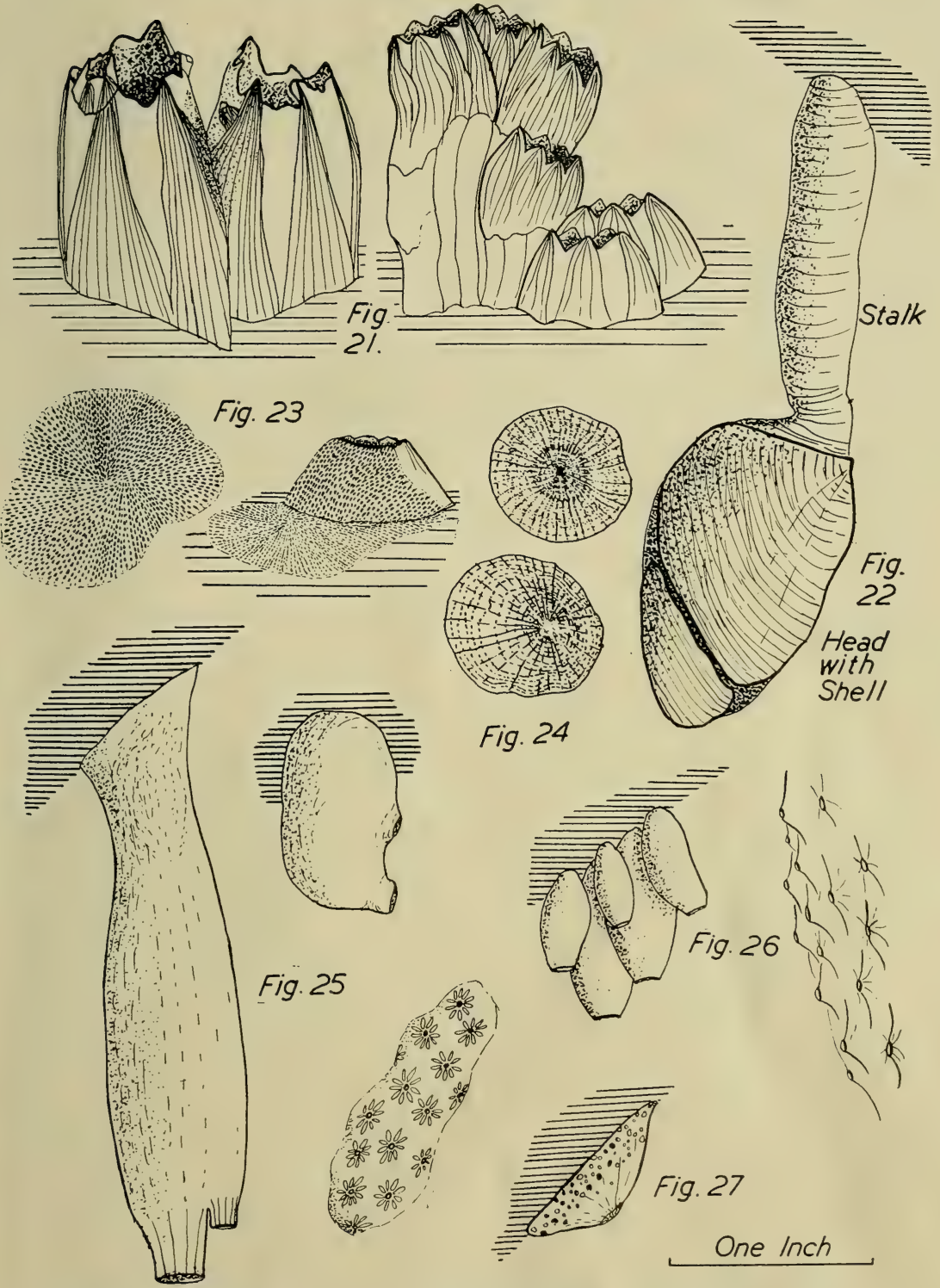

Fig. 21. - "Acorn barnacles," showing the conıpressed forms found in crowded colonies. Fig. 22.-The "goose barnacle." Fig. 23.-Patches of an encrusting Polyzoan, showing how it may grow over the shell of a dead barnacle. The structure is honeycomb-like. Fig. 24. Barnacle bases, showing the type of markings which distinguish them from Polyzoa patches. Fig. 25. - Various sea-squirts, showing two different forms of single animals and a colonial form. Fig. 26. - Sponges, showing (left) a colony of single individuals, and (right) a colonial "encrusting " sponge.

Fig. 27. - A sea-anemone in its contracted form as seen out of water. 
Structures of Various Plant Fouling Organisms.

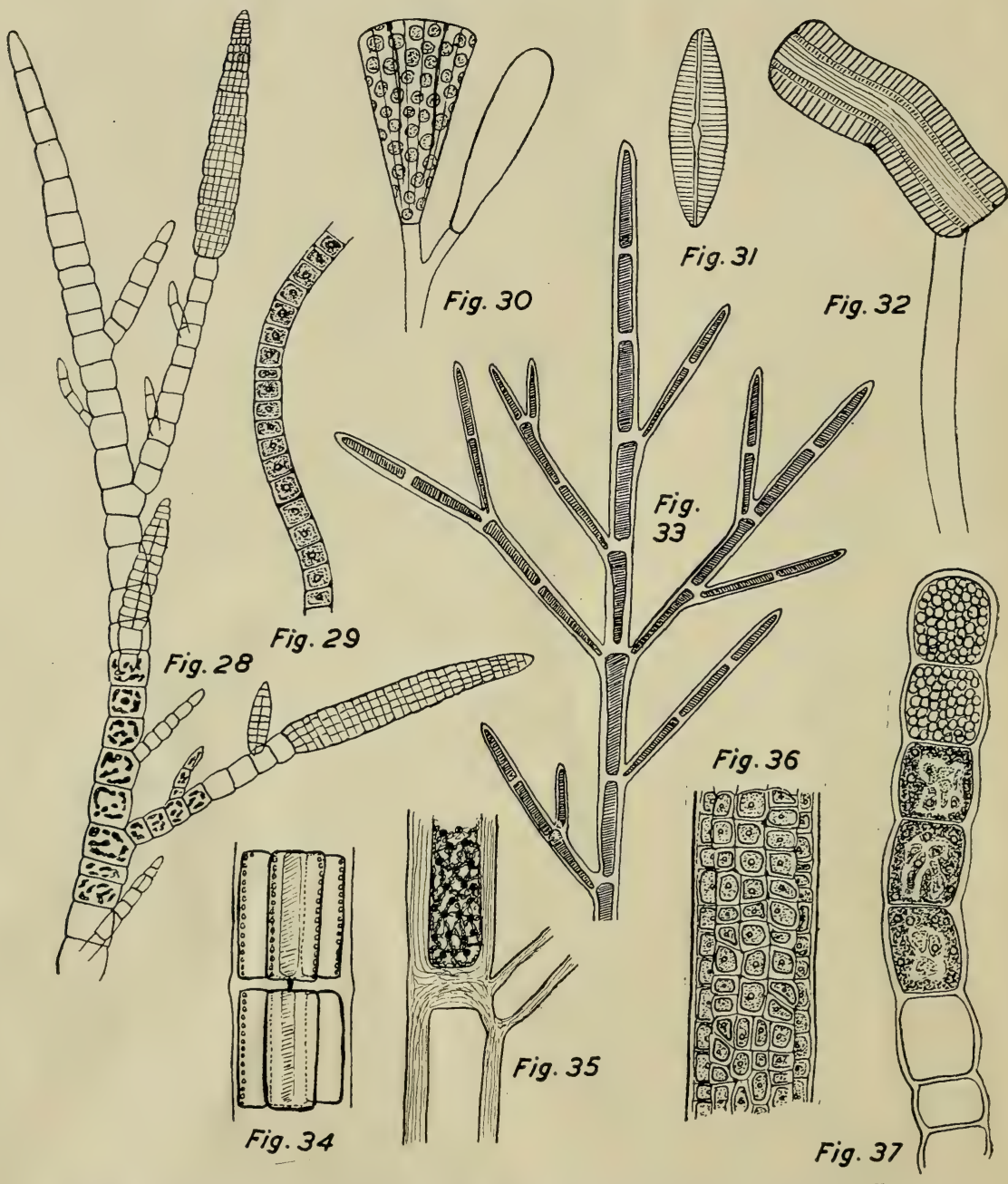

Fig. 28.-Branch of an Ectocarpus, with four of the characteristic reproductive organs; cell contents only shown at the base. $\times 100$. Fig. 29.--Portion of a thread of Ulothrix flacca. $\times 150$. Fig. 30.-Two individuals of Licmophora, seated on the end of the branches of the mucilage stalk and seen in different positions. $\times 300 . \quad$ Fig. 31.-Single individual of Schizonema. $\times 700$. Fig. 32. - Cell of Achnanthes at end of mucilage stalk, $\times 250$. Fig. 33.Tip of a Cladophora, showing shape of cells and manner of branching. $\times 100$. Fig. 34.Two tiers of a Polysiphonia , with four peripheral cells surrounding the single central one. $\times 400$. Fig. 35. - Small part of a Cladophora at a point of branching, showing cell contents and the thick walls. $\times 350$. Fig. 36. - Small part of a strand of Enteromorpha. $\times 150$. Fig. 37.Tip of a thread of Urospora; the two uppermost cells with reproductive cells. $\times 150$. 
Plate VII.

Photomicrographs of Various Seaweeds.

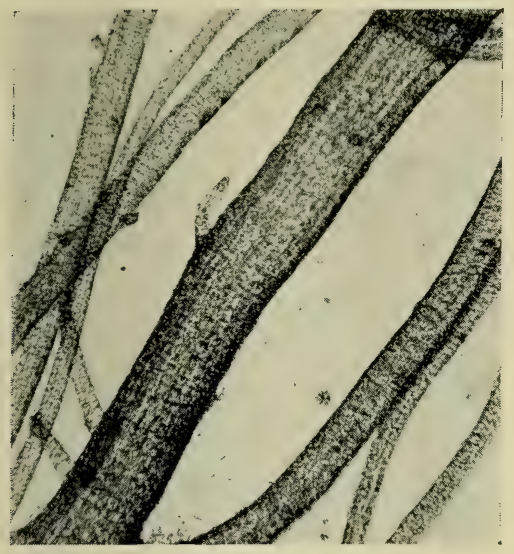

Fig. 38.-A number of strands of Enteromorpha. $\times 70$.

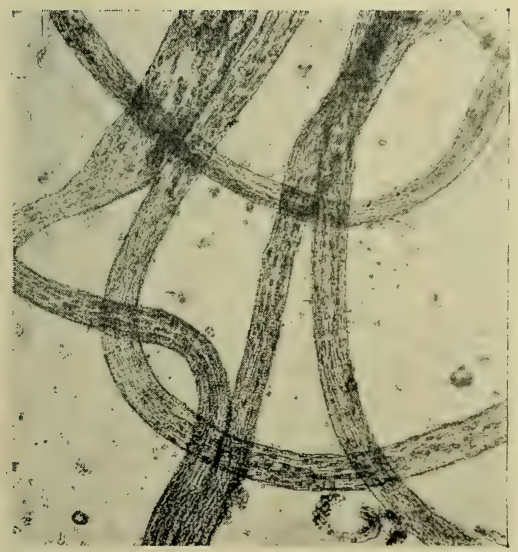

Fig. 40.- The diatom Schizonema in its mucilage tubes. $\times 70$.

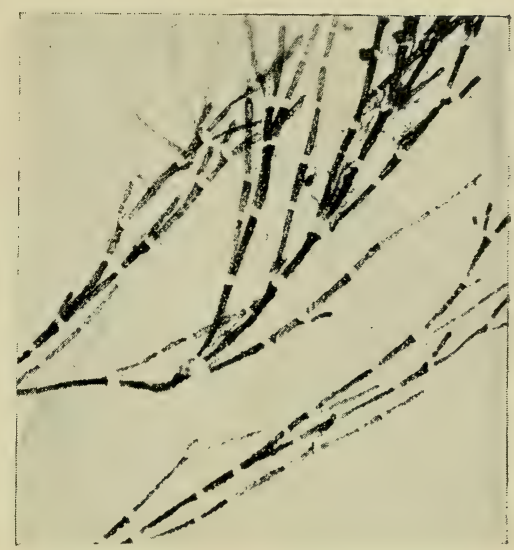

Fig. 39.-Part of a plant of Cladophora, showing the elongated cells. $\times 30$.

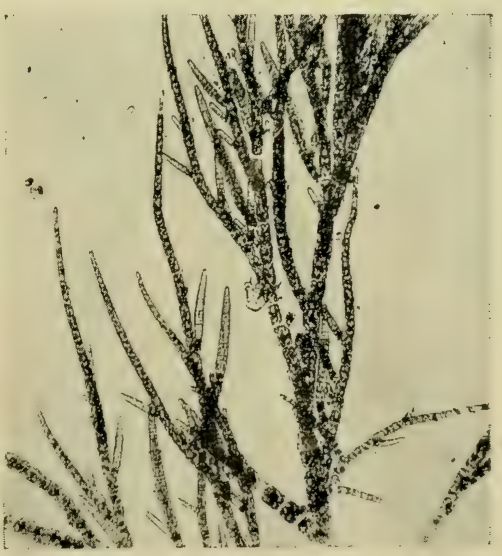

Fig. 41. - The brown seaweed Ectocarpus, showing a number of the reproductive organs. $\times 30$. 
Photomicrographs of Seaweeds and PolyzoA.

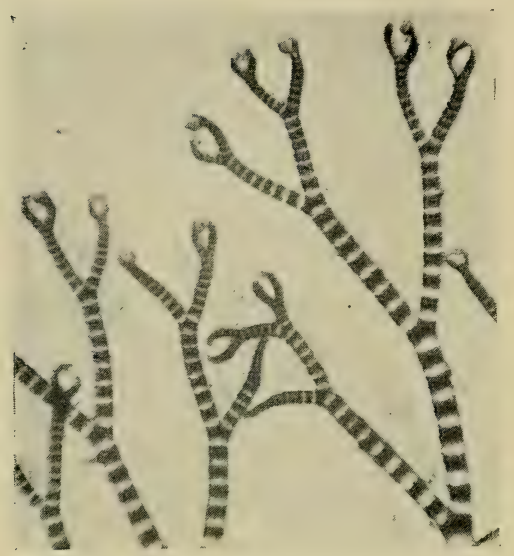

Fig. 42.-The red seaweed Ceramium, showing the characteristic banded appearance and pincerlike endings. $\times 15$.

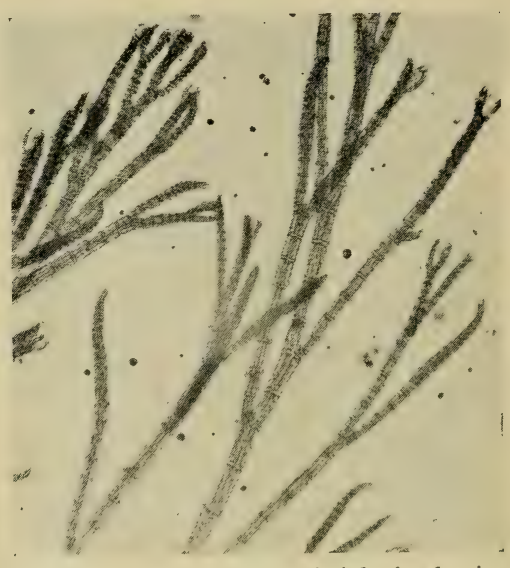

Fig. 43.-The red seaweed Polysiphonia, showing the tiers of cells. $\times 30$.

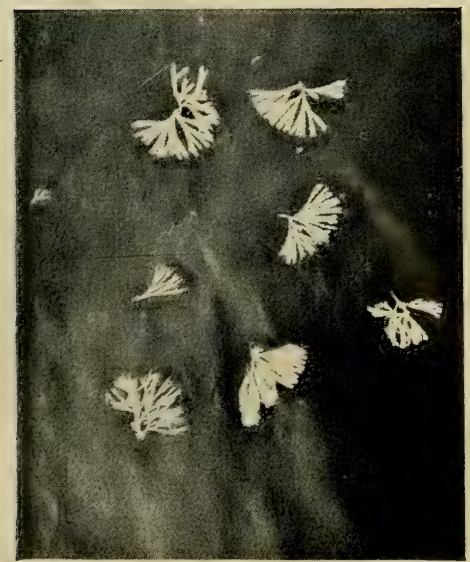

Fig. 44.-A branching Polyzoan. $\times \frac{2}{3}$.

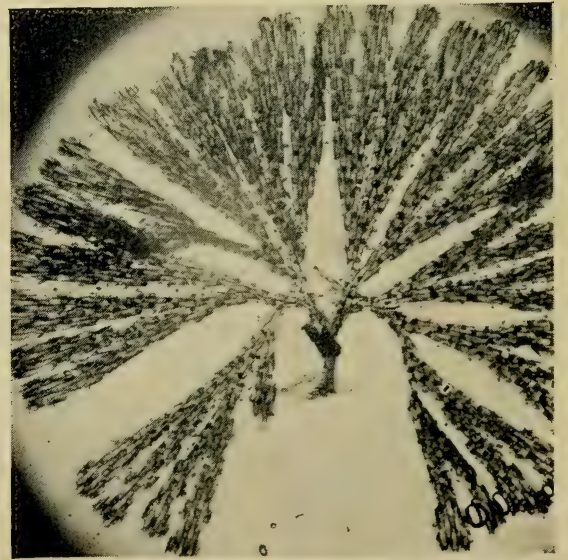

Fig. 45.-The same organism as in Fig. 44, showing the typical honeycomb structure of the Polyzoan. $\quad \times 4$. 
(7) Dry-Docking Report and Key.

A reduced facsimile dry-docking report, which has been filled in for purposes of illustration, is given in the following four pages. Blank copies of this report, printed foolscap size and incorporating the appropriate keys for identification of the organisms, are issued separately and may be obtained from the Secretary of The Iron and Steel Institute. 
Key to Section A of Dry-Docking Report.

(1) Organisms with a Shell:

(a) Conical shells with an opening at the top ("acorn barnacles")

(b) Shells (formed from many plates) at the top of $\}$ BARNACLES. a long fleshy stalk ("goose barnacles")

(c) Small but long tubular shells, lying flat or projecting upwards at the open end, often coiled

(d) Paired shells (like mussels and oysters) TUBEWORMs.

(2) Organisins with no Shell.

(e) Bag-like forms or slimy rounded masses . . Soft-Bodied

Branching types :

ANIMALs.

(f) Stiff stalks, dark brown, grey or white in colour, sometimes ending in knobbed heads

Hyorotos.

(g) Green, brown or red, often branched threads or leafy growths, limp (i.e., lying flat in dry-dock) and near water-line

Seaweed.

The above key is sufficient for the identification of all the groups dis. tinguished in Section A of the dry-docking report. 


\section{DRY"DOCKING REPORT.}

This form, logether with any samples collected, should lic seint to. The Secretary, The Iron and Stecl Institute, 4 Crosvenor Gardens, London, S.W. 1.

Nitime of Vessel : .S.S..YESPEPUS.

Date of Dry-rlocking : .30. Nor..19.4.3

Place : ...RIRK.FNHEAD.

SEctiox 1

The whole of this section should be completerl as far as possiblc

LAST DRY-Dockivg.

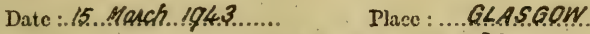

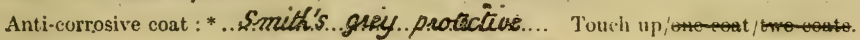

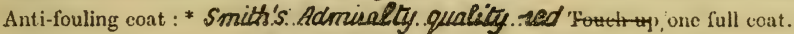

Weather when painted : .. Boak...but fine.

VoXage.

\begin{tabular}{|c|c|c|}
\hline Porte of Call. & $\begin{array}{l}\text { Arrival } \\
\text { Date. }\end{array}$ & $\begin{array}{c}\text { De. } \\
\text { parture } \\
\text { Date. }\end{array}$ \\
\hline Alexandria & $15 \div 14 .-633$ & $19:-4-43$ \\
\hline Ader ........... & $23-4=43.3$ & $27:-4: 43$ \\
\hline Boranbo. & $5:-5: 43$ & $19: 5: 16^{3}$ \\
\hline Perth....... & $9-5 .=43$ & $12: 6: 4: 3$ \\
\hline Sydney.. & $22.6-43 !$ & $22: 7: 43$ \\
\hline Dusban... & 22:-9:4.3. & $.5-9 \div 43$ \\
\hline fsectown. & $26: 9: 4.3$ & $10-10: 113$. \\
\hline Liverpark. & $3 .-11=43$. & \\
\hline
\end{tabular}

Paint Condition on Botrom.
Foctuxe.

\begin{tabular}{|c|c|c|c|}
\hline \multirow{2}{*}{ Kint. } & \multicolumn{3}{|c|}{ Amount $\ddagger$ and Position. } \\
\hline & Sirles. & Bottom. & Propellers. \\
\hline Barnacles & & ..XX. & \\
\hline Tubeworms & & & $\ldots X \ldots \ldots$ \\
\hline Iftussels or Oy's & & $\ldots x$. & \\
\hline Soft-botlie: for & & & \\
\hline Hydroids . & ........... & .... & \\
\hline Weed (green). & $\ldots X$ & & \\
\hline Weed (brown) & $\ldots \ldots$ & . & \\
\hline Weed (red) & . & & \\
\hline
\end{tabular}

¥ The anount of fouling should be show: thus : $\times$ little $\times \times$ much.

\begin{tabular}{|c|c|c|c|c|c|c|c|c|c|c|c|c|}
\hline & \multirow{3}{*}{ Pain } & & & & \multicolumn{4}{|c|}{ Pонт. } & \multicolumn{4}{|c|}{ StarboARd. } \\
\hline & & & & & \multirow[b]{2}{*}{ Forward. } & \multicolumn{2}{|c|}{ Amidships. } & \multirow[b]{2}{*}{ Aft. } & \multirow[b]{2}{*}{ Forwant. } & \multicolumn{2}{|c|}{ Asnidships. } & \multirow[b]{2}{*}{ Aft } \\
\hline & & & & & & $\begin{array}{l}\text { Abnve } \\
\text { Bilgo- } \\
\text { Kicel. }\end{array}$ & $\begin{array}{l}\text { Below } \\
\text { Bilge- } \\
\text { Keel. }\end{array}$ & & & $\begin{array}{l}\text { Abovo } \\
\text { Bilge. } \\
\text { Keel. }\end{array}$ & $\begin{array}{l}\text { Below } \\
\text { Bilge- } \\
\text { Keel. }\end{array}$ & \\
\hline $\begin{array}{l}\text { Good }{ }^{2} \\
\text { Fair }^{2} \\
\text { Bad }^{3}\end{array}$ & $\vdots$ & : & $\dot{.}$ & : & $x$ & $x$ & $x$ & $x$ & $x$ & $x$ & $x$ & $x$ \\
\hline \multicolumn{5}{|c|}{ Intact anti-fouling coating. $\% 4$} & 25 & 1 & 80 & 50 & 40 & 5 & 50 & 50 \\
\hline
\end{tabular}

1 Goorl.-Paint generally firm and adherent, rusted and baro tress nit exeeding $2 \%$ of the total area.

- Fair.-Rusted and bare areas from 3 to $9^{y}$, of the total nren.

3 Bad.-Rusted and bare areas $10^{\circ}$ or more of the total urea.

Enter a $X$ in each column opposite the appropriate condition.

- Insere the percantage areas in each columa.

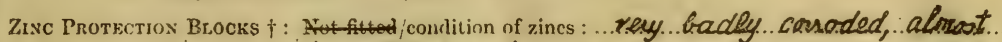
........ dis apprared an . Staubard.. Side.

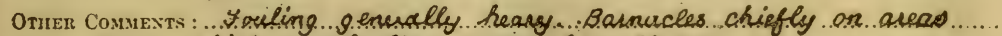
..... furm ... utrich antiforeling.. coating ...had flaked. 


\section{Dry-Docking Report-Continued.}

\section{SECTION $B$.}

Thesequestions are less important than those in Section A overleaf, but answers to any or all of them will provide very useful information.

Special Notes on Fouling.

1. Slime.* Present//liatom.

2. Weed. (If individual types of weed can be identified (using the pamphlet on "The Fouling of Ships' Bottoms" or the key below) enter the names and amount (as $x$ or $x \times$ ) of cuch in

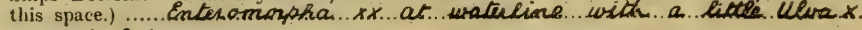
... and ... Ectorcaypus. $x$.

3. Barnacles: Size : * Large/medium/medh. Colsur : * Whito/purple or blue:

4. Molluscs.* /oysters. Buting/gratings only.

5. Polyzoa* ; /branched forms.

6. Soft-bodied forms.*

7. Any other forms. (Give brief description and senil sample if possible.)

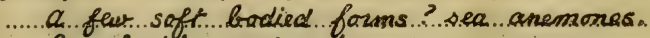
...... Sample ...ube enclaseal.

8. Special Notes (e.g., if port and slarboard sides very differently fouled or if fouling limited to certuin special areas. Any information us to where fouling was first encountered on the voyage, lergth of uced or diumeter of barnacles on docking, etc.).

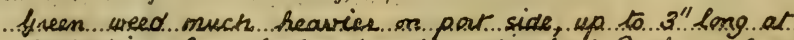

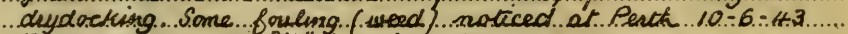

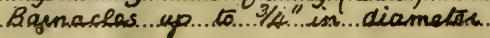

Signalure : \$ Sones. Position in Firm or ship Doxk.. Supecintendeut

- Cross out remarks which do not apply. 
Key to Section B of Dry-Docking Report.

(See also key to Section $A$ if required.)

(1) Organisms with a Shell.

(h) Flat patches of a limy encrustation, honey. comb in structure

Polyzoa.

(2) Organisms with no Shell.

(i) Branching types:

(i) Branches expanding from a single base or forming a moss-like tangle; never possessing heads on the stalks and showing a honeycomb structure under a good lens .

(j) Green weeds :

(1) Soft and flexible tubes, varying in thickness from that of human hair to about $\frac{1}{4}$ in. or more, usually little branched

PolyzoA.

(2) Single threads, with a slimy feeling, of the thickness of a human hair or much narrower, the individual cells in the wider threads just recognisable under a good lens :

(3) Richly branched threads, forming tufts 1-2 in. long, with a rather harsh feeling, the long component cells readily seen with a lens

(4) Broad papery sheets : . .

ENTEROMORPHA.

\section{URospora:}

Cladophora.

ULVA.

(k) Brown weeds :

(1) Threads forming short tufts or long hanging tresses, usually extensively branched, but the majority of the branches much narrower than those of Cladophora. (N.B.- These growths may appear green after a stay in fresh water) .

(2) Similar branching threads, with a more slimy and softer feeling than those of Ectocarpus; under a microscope are seen to consist of mucilage tubes harbouring boat-sh.?ped diatoms

Schizonema.

(l) Red weeds :

(1) Branched threads, often repeatedly forked, the two arms of the ultimate forks often curved inwards like a pair of tongs; threads with alternating darker and lighter cross bands

Ectocarpus.

(2) Branched threads, in which the elon-

Ceramium. gated cells are arranged in successive horizontal rows, especially obvious in the upper parts

Polysiphonia.

(ii) Soft-bodied forms:

(m) Jelly-like masses or transparent leathery bags

(n) Opaque bag-like or spongy structures.

Sea-Squirts, Sponges. 
(8) Notes on the Recognition of Specific Organisus.

(a) Diatom Slimes.

Among the types of diatoms responsible for fouling are species of Schizonema, in which numerous individuals live within a branching system of mucilage tubes (Fig. 40). The individual cells, according to the position in which they lie, appear rectangular or more usually boat-shaped, tapering from the middle towards each end (Fig. 31). Other diatom slimes are of a different character, the cells being situated at the ends of rather thick, simple or branched, transparent mucilage stalks, which are themselves attached to the ship's hull. The commonest of these, due to a diatom called Achnanthes, is readily recognised $(\times 50)$, because the individual cells either appear oval or exhibit a marked bend in the middle (Fig. 32), according to the side which faces the observer. Less frequently diatoms are found with wedge-shaped cells borne on mucilage stalks. These, Licmophora (Fig. 30), usually grow attached to other seaweeds. Many other kinds of diatoms occasionally occur in the growths on fouled vessels, but these are rarely abundant and could only be identified by an expert.

\section{(b) Plants.}

Among the green seaweeds the commonest is Enteromorpha (Figs. 2 and 38), which possesses soft and rather flexible threads, frequently unbranched, although a few kinds branch freely. Under the microscope $(\times 50)$ the threads can be seen to resemble a hollow green tube, a layer of small cells surrounding the central hollow. The cells are commonly arranged in longitudinal rows (Fig. 36). In some of the coarser kinds the tube-like character is recognisable without microscopic examination. The strand of Enteromorpha may grow to a length of $6 \mathrm{in}$. or more.

Less commonly the green seaweed Cladophora (Figs. 4 and 39) is concerned in fouling. This occurs in dense tufts, which are richly branched and usually from 1 to 2 in. long. They have a coarser "feel" than the growths of Enteromorpha, and with a good handlens can be seen to consist of simple rows of long cells (Fig. 33), much larger than those forming the surface of the Enteromorpha tube. The branches commonly arise in twos or threes at the same point (Fig. 33).

Occasionally green fouling is due to Urospora; this has unbranched hair-like threads, which, when handled, have a rather slimy feeling. Structurally $(\times 100)$ they show a single row of broad, often barrel-shaped, cells with rather thick walls and dark green contents (Fig. 37). The shape and size of the cells are very variable.

In the early stages of fouling very much narrower threads with small cells are sometimes found; they belong to the seaweed Ulothrix flacca (Fig. 29), and are recognisable onlv under a microscope ( $\% 100)$. Such threads sometimes occur within the diatom slimes. 
Species of sea lettuce (Ulva) may also be met with on ships' hulls, although, so far as present experience goes, they always occur in association with some of the other green forms. One of the commonest kinds grows in broad sheets of about the thickness of tissue paper and is readily recognised (Fig. 3), but some kinds of Ulva produce relatively narrow ribbons that are not always easily distinguished from some types of Enteromorpha.

Of the brown seaweeds responsible for fouling one of the very commonest is Ectocarpus, of which there are a number of different kinds. Its tresses are usually dark brown, and when spread out are seen to be richly branched (Figs. 6 and 41). Some kinds are less than an inch long and, if there is a dense growth of Enteromorpha, for instance, may be completely hidden beneath it. Other kinds of Ectocarpus may grow to a length of several inches. Under the microscope the contents of the cells appear brown or yellowishbrown, although if the vessel has been for some hours in a fresh-water port the brown colour will have leached out and the contents may look green. Some or many of the shorter branches will be found to end in oval or elliptical structures, consisting usually of several rows of minute cells, much smaller than those composing the other parts of the seaweed (Fig. 28). These distinctive structures are the reproductive organs of Ectocarpus.

Other brown seaweeds that may occur on ships' hulls are coarser and less richly branched, but these are rare and have not usually reached their full growth, and it would require an expert to name them. The most frequent is Scytosiphon, with hollow strands resembling those of Enteromorpha. The bladder-wrack (Fucus) and the oarweeds (Laminaria) (Fig. 5) are likely to settle only on a heavily fouled vessel which has made a long sojourn in port. They would almost certainly become detached when the ship began to move through the water.

Of the red seaweeds likely to occur on ships' hulls the two most easily recognised are Ceramium (Fig. 7) and Polysiphonia (Fig. 8). Both appear as richly branched tresses, usually l-3 in. long; those of Ceramium are mostly bright red, those of Polysiphonia often dark purple, sometimes appearing almost black. When the tips of the threads of Ceramium are examined under a hand-lens (Fig. 42) they usually appear forked, the two arms of the fork often being curved inwards like a pair of tongs. The threads themselves show numerous cross bands which are of a darker colour than the intervening portions. These two features are quite distinctive of Ceramium. Under a microscope $(\times 100)$ the banded appearance is seen to be due to the fact that the large cells forming the threads of this seaweed are covered at regular intervals by sheets of smaller cells.

The threads of Polysiphonia are usually coarser. The upper (i.e., younger) parts, when viewed with a hand-lens, show an arrangement of cells in horizontal tiers which is very characteristic and is even more obvious at a magnification of $\times 50$ (Fig. 43). The 
individual tiers may consist of from four to twenty longish cells (Fig. 34). The walls of the cells are usually thick. Sometimes some of the branches are irregularly swollen and harbour a number of very deeply pigmented cells, often in groups of fours; these are the reproductive cells of Polysiphonia.

\section{(c) Animals.}

When an acorn barnacle is scraped off the hull surface it generally leaves a circular plate of lime still attached to the paint (Figs. 16 and 24). There is, however, one, type of fouling organism which rather closely resembles a barnacle base and should be carefully distinguished from it. This is known as a Polyzoan and produces another form of "coral patch" on the surface (Figs. 15 and 23). The Polyzoan encrustation has a fine net-like or honeycomb structure composed of numerous small cells, while a barnacle base resembles a fish scale.

Polyzoa also occur as flexible branching forms (Fig. 44), as well as in the " coral patch " form. They are difficult to distinguish from plant and hydroid growth, though their fine honeycomb structure is generally visible under a hand-lens (Fig. 45).

Jelly-like masses, found usually on ships moored for a long time in richly infested waters, may be sea-squirts (Figs. 19, 20 and 25) or sea-anemones (Fig. 27). A thick leathery bag of jelly which ejects water voluntarily or when compressed (sea-squirts), or a coloured or white flattened blob of jelly, is typical of such animals.

Sponges, sometimes found under similar circumstances, are more bag-like in structure with a rough surface. They have either a single large opening to the bag or a very large number of such openings from a colony (Figs. 19 and 26). 


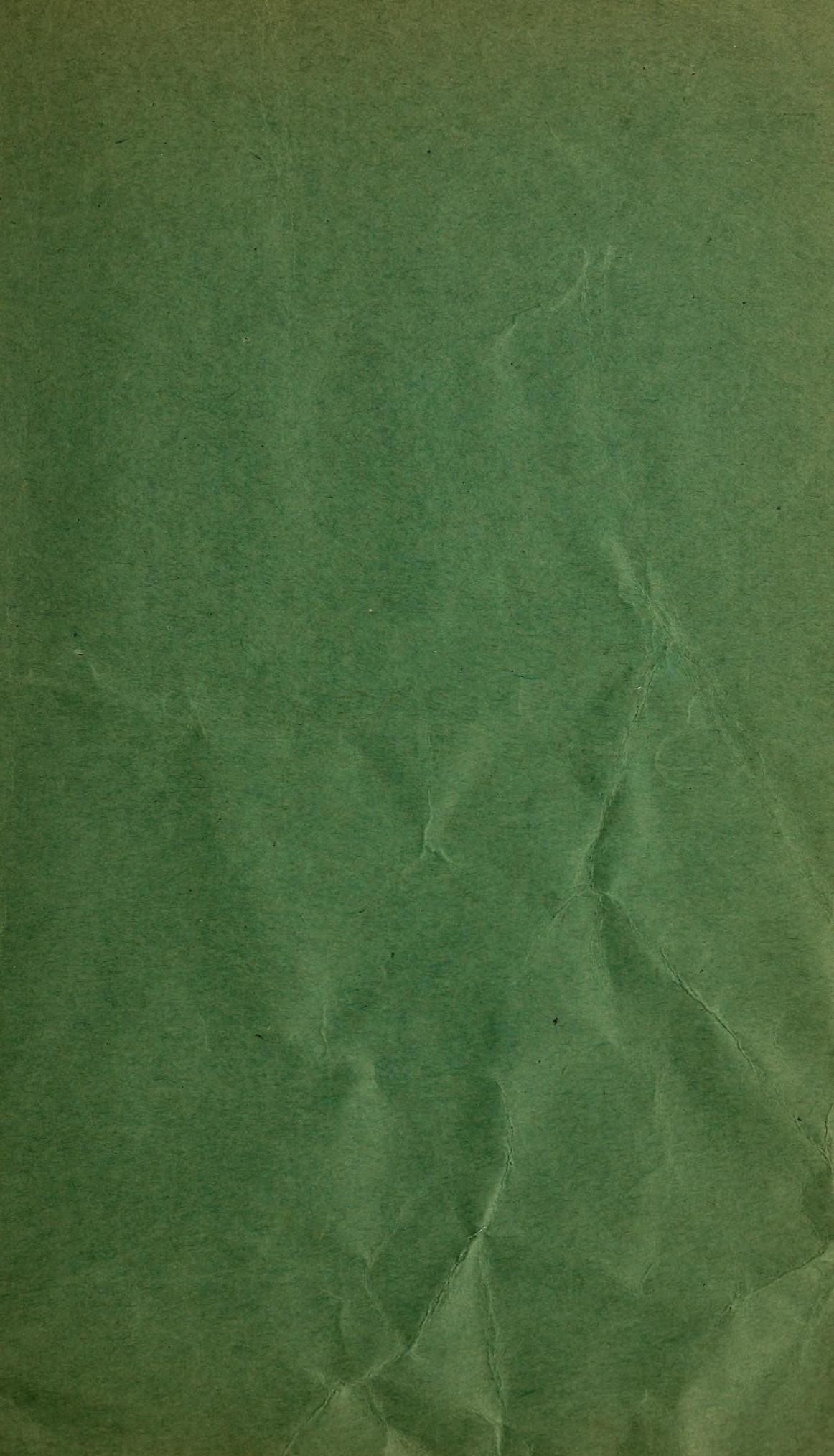



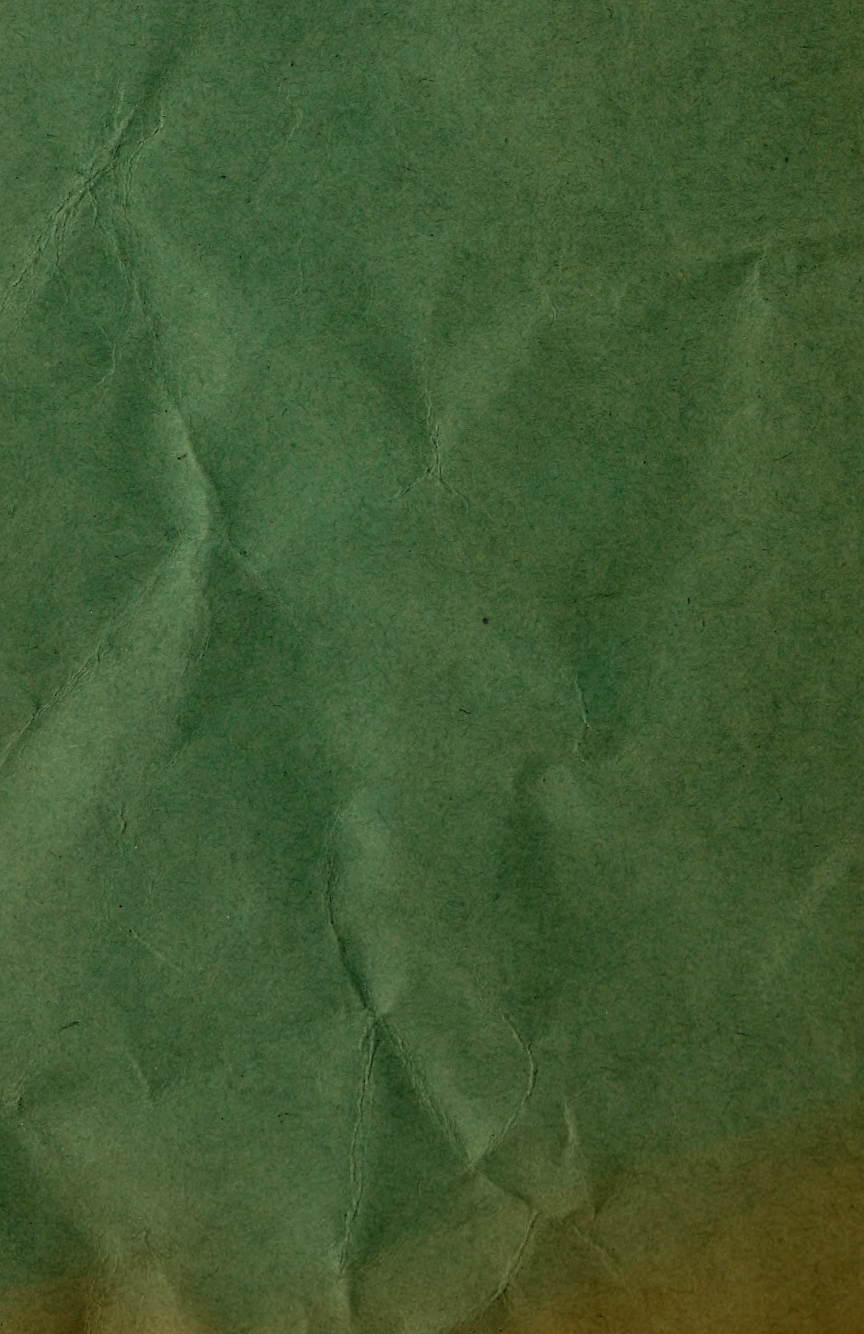